OPEN ACCESS

International Journal of Management \& Entrepreneurship Research

P-ISSN: 2664-3588, E-ISSN:2664-3596

Volume 2, Issue 4, P.No. 194-211, August, 2020

Fair East Publishers

Journal Homepage: www.fepbl.com/index.php/ijmer

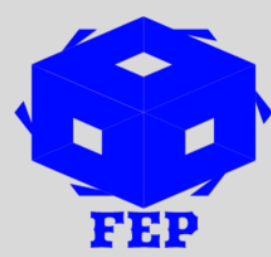

\title{
RURAL HOUSING CHALLENGES IN THE UPPER WEST REGION OF GHANA: A CASE STUDY OF KULMASA
}

\author{
Justice Agyei Ampofo ${ }^{1,2}$ \\ ${ }^{1}$ University for Development Studies, Tamale (Ghana) \\ ${ }^{2}$ University of Education, Winneba (Ghana)
}

*Corresponding Author: Justice Agyei Ampofo

${ }^{1}$ Corresponding Author Email: papajusty@gmail.com

Article Received: $12-07-20$

Accepted: 20-08-20

Published: 05-09-20

Licensing Details: Author retains the right of this article. The article is distributed under the terms of the Creative Commons Attribution-NonCommercial 4.0 License (http://www.creativecommons.org/licences/by-nc/4.0/) which permits non-commercial use, reproduction and distribution of the work without further permission provided the original work is attributed as specified on the Journal open access page.

\begin{abstract}
Housing is one of the most basic needs of human beings but many people find it difficult to afford. This is why there are many housing shortages in most parts of the world especially in developing countries. There seems to be paucity of studies on rural housing challenges in Ghana in general and Kulmasa community in the Upper West Region of Ghana in particular. This research seeks to bridge this knowledge gap by assessing rural housing challenges in the Upper West Region of Ghana using Kulmasa as a case study area in order to come out with interventions to address these housing challenges. Study methods include the use of questionnaire, interview guides and observation checklist for data analysis. A total of 66 respondents (both male and female) who took part in this study were purposively selected. The results indicated that the existing housing conditions in Kulmasa community in the Wa Municipality of the Upper West Region of Ghana are in substandard state. The study found out that cultural reasons, proximity to place of work, environmental friendliness of the area, accessibility and affordability of the land and availability of better infrastructure are factors influencing housing development in Kulmasa community of the Upper West Region of Ghana. The study found out that lack of access to secure land, limited access to finance, high cost of land registration, slow bureaucratic procedures, lack of infrastructure in rural areas, development controls, uncoordinated policies and implementations, high cost of construction and high price of land are some of the challenges of the existing housing conditions in Kulmasa community of the Upper West Region of Ghana. It is recommended that the government of Ghana should provide enabling environment for private sector to provide safe, adequate and affordable housing for people in rural communities in the Wa Municipality of
\end{abstract}


the Upper West Region of Ghana. Again, the study recommends that the government of Ghana should liaise with banks and set up social housing mortgage scheme for the people of Kulmasa community. This entails interested banks pooling reasonable sum of money together for lending to the people of Kulmasa community at a negotiated but reduced interest rate of say $5 \%$ or less.

Keywords: Rural, Housing, Challenges, Kulmasa Community, Wa Municipality, Upper WestRegion, Ghana.

\section{INTRODUCTION}

Housing is one of the most basic needs of human beings (Ampofo, 2020). A house is literally defined as buildings or structures that provide cover from weather or protection against danger, a building in which people live, a dwelling (Aboagye, 2011; Ampofo, Amoah \& Peprah, 2020). Housing is an important sector of a nation's economy because a vigorous and buoyant housing sector is an indicator of a strong program of national investment and is the foundation and first step to future economic growth and social development (Danso, 2013).

As part of the environment, housing has an influence on the health, social behavior and the general welfare of a community (Ampofo, Amoah \& Peprah, 2020). Due to its importance to the welfare, survival and health of individuals, concerns have been raised both internationally and municipally over housing challenges in urban areas of developing countries across the world. This issue was highlighted at the United Nations Habitat I Conference held in Vancouver in 1976, the International Year of Shelter for the Homeless in 1987 and at the Habitat II Conference held in Istanbul in 1996. As a result of the publicity through governmental and non- governmental agencies such as the United Nations, attention has been paid in most developing countries by researchers, professionals, decision makers, etc to the housing challenges (that is overcrowding, deteriorating environments, etc) and to the design of housing policies to solve these problems.

According to Ampofo (2020) housing shortages still persist in most parts of the world especially in developing countries among which is Ghana especially the Upper West Region. According to UN-HABITAT (2010), more than "one billion human beings still lack adequate shelter and are living in unacceptable conditions of poverty" (Habitat Agenda, paragraph 53). The majority of these people live in developing countries of which Ghana is inclusive and as a result of the urbanization of poverty, an increasing number of these people live in urban areas. Informal houses/ urban squatter settlements comprise between 30-70 percent of the housing stock in many towns and cities in developing countries across the globe (UN-Habitat, 2012).

Ghana, a country with 16 regions is among the most populous countries in Africa.

The Ghanaian population in 2018 was estimated about 29.6 million and a (GSS, 2018). Like most of its counterparts in the developing countries, Ghana has housing shortages, with a high percentage of its citizens living in poor quality housing and in unsanitary environments (that is informal houses and slums). This problem of inadequate housing is a result of the rapid rates of urbanization and economic growth. This urbanization is as a result of rural-urban migration, which is caused by the lack of development, infrastructure (water, roads, telecommunication, electricity etc) and the poor economic conditions of the rural dwellers. The absence of these amenities leads to migration of rural dwellers into urban centers in Ghana. Research has it that 
the population of Ghanaians living in urban centers has increased rapidly over the years. The movement of this population in urban centers has created severe housing problems, resulting in overcrowding in inadequate dwellings, high rents, low infrastructure services, deteriorating environment and rise in urban insecurity just to mention few (Yeboah, 2005; Ampofo, Nassè, Amoah \& Peprah, 2020).

Construction of informal houses is on the increase in cities in Ghana. Also, this problem of poor housing prevails in the rural fringes. This is because the schemes or polices have failed in providing the less privileged people with sustainable and affordable houses as such rural housing development in the Upper West Region, Kulmasa in particular has manifested many deficiencies worthy of conducting research on. These problems include; the use of perishable materials, weaker technological advancement, poor living environment, inadequate utilities, facilities and services, lack of funds and many more.

In view of this, it has been considered necessary to assess the housing challenges in the Upper West Region using Kumalsa as a case study area in order to come out with interventions to address these housing challenges.

The study was guided by three specific research objectives:

1. To determine the nature of the existing housing conditions in Kulmasa community of the Upper West Region of Ghana.

2. To identify the factors influencing housing development in Kulmasa community.

3. To assess the challenges of the existing housing conditions in Kulmasa community.

\section{REVIEW OF RELATED LITERATURE}

\section{Housing Conditions and Supply in Rural Areas in Ghana}

Housing is a basic necessity of life of every nation and the quality of housing used by any household establishes a fundamental basis for assessing the standard of living of that household and to some extent, the nation as a whole. An improved investment in the housing sector is one of the effective means of ensuring that households have access to basic services such as water and effective sanitation (UN-Habitat, 2010). In Ghana, once a building permit is acquired, there are no effective steps to ensure that houses conform to acceptable standards. Developers or households do not see the need for a permit either to extend a building structure or even alter any part of a building. Monitoring to ensure housing quality is therefore lacking in the building sector as the 2011 UN-Habitat report on Ghana indicates.

Most housing is built in horizontal stages progressing vertically through the whole foundations, the walls and the roof, only being occupied by the homeowner when it is finished (UN-Habitat, 2012. p. 168; Ampofo, 2020). An assessment of the housing sector by Kumar (2001) shows that "a disproportionate share of deficient housing stock is located in the northern, Upper Savannah belt of Ghana (i.e. the Upper East, Upper West and the Northern regions)" (p. 157). The UN-Habitat (2011) report on housing in Ghana and poverty reduction confirms that rapid urbanization in the cities of Ghana and Africa as a whole has affected the institutional capacity to deliver not only affordable housing but durable and high-quality shelter that meets the health need of urban dwellers.

\section{Factors Influencing Housing Supply in Rural/Urban Areas in Ghana}

Housing is a basic necessity of life of every nation and the quality of housing used by any household establishes a fundamental basis for assessing the standard of living of that 
household and to some extent, the nation as a whole. An improved investment in the housing sector is one of the effective means of ensuring that households have access to basic services such as water and effective sanitation (UN-Habitat, 2010). In Ghana, once a building permit is acquired, there are no effective steps to ensure that houses conform to acceptable standards. Developers or households do not see the need for a permit either to extend a building structure or even alter any part of a building. Monitoring to ensure housing quality is therefore lacking in the building sector. As the 2011 UN-Habitat report on Ghana indicates.

According to Aboagye (2011) socio-economic circumstances, cultural background, world views, and the political and economic situation of the country are determinants of users' housing needs. In order to capture the needs of the rural populace in housing policies, an indepth understanding of housing values of the prospective beneficiaries of the policies must be taken into cognizance by the policy makers. Kumar (2001) describes housing values as the preferences and choices that people consider in housing selection. This is in line with Ampofo et al (2020)'s definition: "the underlying criteria for choice in housing and other aspects of life". Yeboah (2005) came up with four hierarchy of values: economy, family (physical, mental health and family centrism), personal (aesthetics, leisure and equality) and social storage.

There is virtually no African country that does not face daunting housing problems (Ampofo, Amoah \& Peprah, 2020). One common denominator runs through the challenges that these countries face. This is the lack of well-established housing institutions that provide a satisfactory policy framework to ensure adequate supply of housing not only for the increasing market in urban areas but most especially to clear the backlog of housing demand. Rapid urbanization is one of the contributory reasons for the housing problem.

There is a range of issues that compound the housing situation in the continent. As Ampofo et al (2020) argued, even though urban centers in the African continent are not well developed to global standards to be able to accommodate the increasing population, these countries are experiencing the fastest growth rates in the world today. Yeboah (2005) also noted that the rate at which urbanization is taking place in the cities of Africa is very rapid. All over the continent cities are drawing more and more people in search of economic opportunities some of which are practically non-existent and the majority of these people end up dwelling in informal settlements including slums (Alan, 2008).

Scarcity of land as a result of the increasing population in urban areas is a major factor that contributes to the low supply of housing. The UN-Habitat 2011 report on affordable land and housing in Africa indicates that "the continued growth and expansion of African cities has increased the gap between the supply and demand of urban land and housing. Urban land for housing development is increasingly scarce, poorly regulated and therefore expensive" (UNHabitat, 2011). Ampofo (2020) notes that even though land supply is limited everywhere, the nature of the land problem in Africa is exceptional and therefore compounds the problem of land supply in urban areas. This is because land ownership in Africa is communal and is traced to tribal lines.

\section{Challenges of Housing in Rural/Urban Areas in Ghana}

Despite the potency of boosting national development through housing, the Ghanaian housing sector has suffered setbacks in various facets and at several stages. According to Ampofo (2020), the housing and construction sector in Ghana accounts for only about 1 percent of the 
country's rebased gross domestic product. There is need to particularly focus on the development of housing in the rural areas because a considerable proportion of Ghanaians live in the rural areas (Yebaoh, 2005).

According to Alan (2008) the relationship between the urban and rural areas are symbiotic and if any development strategy must be successful, it must recognize that the phenomenon of rural - urban dichotomy in the national landscape is unacceptable and connotes underdevelopment. Moreover, many of the problems of the urban areas can be traced to shortcomings in the rural areas. The mass exodus into the towns is worrisome. The high costs of urban housing and services, the health hazards of shanty towns, the security and political threat posed by the urban unemployed and the adverse economic implications of rural depopulation - these are all challenges which result from the influx into towns and cities (Kwofie, 2011). Many areas in Ghana suffer from severe pressures on available resources, such as housing, thereby worsening already bad situations in urban employment, management, service delivery and livability (Kwofie, 2011).

Despite having a considerable proportion of the national population, the rural areas are characterized by pervasive and endemic poverty, manifested by widespread hunger, malnutrition, poor health, inadequate access to formal education, deplorable housing state and various forms of social and political menace. Most of these challenges are not as severe in urban areas when compared to the rural areas.

\section{Research Design}

\section{METHODOLOGY}

The research is a descriptive survey through which views and opinions were sampled from respondents. Creswell (2013) views descriptive survey as a design that portrays accurately the characteristic of particular individual situations or groups. In other words, the descriptive survey is a research method that is non-experimental and deals with the relating among nonmanipulated variable. A descriptive survey also provides a quantitative or numeric description of trends, attitudes, or opinions of a population by studying a sample of that population. It includes cross-sectional and longitudinal studies using questionnaire or structured interviews for data collection, with the intent of generalizing from a sample to a population (Ampofo, 2019).

The descriptive survey was considered the most appropriate design for conducting this research because information gathered from the descriptive research can be meaningful or useful in diagnosing a situation since it involves describing, recording, analyzing and interpreting conditions that exist. The descriptive survey was again considered the most appropriate design for conducting this study because it is the one that deals with things as they currently are (Ampofo, 2017:2019:2020).

Descriptive survey design also helped in achieving the goal of the study, which was to assess the housing challenges in Kumalsa community of the Upper West Region of Ghana. According to Kusi (2012), survey permits the researcher to gather information from a large sample of people relatively quickly and inexpensively. Most surveys are based on samples of a specified target population - the group of persons whose interest is expressed. They are designed to provide a 'snapshot of how things are at a specific time'. There is no attempt to 
control conditions or manipulate variables (Lee, 2000; Cohen, 2007: Hite, 2010; Ampofo, 2020).

Creswell (2013) view that descriptive survey predominantly aims at describing, observing and documenting aspects of a situation as it naturally occurs rather than explaining it. To him, the design had an advantage of producing a good amount of responses from a wide range of people. A descriptive survey involves asking some set of questions to a large number of people either by mail, telephone or in person. At the same time, it provides a more accurate picture of events and seeks to explain people's perception and behavior on the basis of data gathered at a point in time.

\section{Data Sources}

The research outsourced information from both secondary and primary data.

\section{Secondary Data}

The secondary data was obtained from other research works relating to the housing challenges in Ghana and other Countries for the purposes of making inferences through comparison. Information was also obtained from some key informants such as the chief and Assembly man of Kumalsa community on issues relating to the housing challenges in their area.

\section{Primary Data}

The primary data was the raw information taken solely from the field and this was gathered using the following methods, tools and techniques;

- Questionnaire (both open and close ended)

\section{The Study Area}

The location for this study is the Kumalsa community in the Wa Municipality of the Upper West Region of Ghana. As compared to their counterpart of communities in the Wa Municipality there are more concern on the housing challenges in Kumalsa which has been an issue of concern among people in the area and this need to be investigated into. The location for the study is within the researcher's locality hence reducing the cost as well as risk involved in travelling. This makes the data collection process easy and convenient.

\section{Population}

The population consisted of all the people residing and living in Kumalsa community who are eighteen years and above renting or owing a house. These people are the targeted population because there are more likely to have an idea about housing challenges. The total number of people who are eighteen years and above residing and living in Kumalsa are numbered 200. Therefore, the total population of this study was 200 .

\section{Sample Size}

To realize the main objective and specific objectives for this study a total of 66 respondents took part in this study were randomly sampled. This random sampling was scientifically done for all the population using Miller and Brewer (2003) formula shown below:

$$
n=\frac{N}{1+N(\propto)^{2}}
$$

Where: $n=$ required sample size, $1=$ constant, $N=$ sample frame, $\propto=$ level of significance or margin of error. 
Table 1

Sample Size of Respondents Calculated using Miller and Brewer (2003) Formula above

\begin{tabular}{ll}
\hline \multicolumn{2}{l}{ Sample Size Determination For Respondents } \\
\hline SAMPLE SIZE $(\mathrm{n})$ & $?$ \\
TOTAL POPULATION & 200 \\
CONSTANT $(1)$ & 1 \\
ERROR TERM $(\mathrm{e}) \%$ & $10 \%$ \\
Exponent & 2 \\
$\left(\mathrm{~N}(\mathrm{e})^{\wedge} 2\right.$ & 2 \\
Factor $1+\left(\mathrm{N}(\mathrm{e})^{\wedge} 2\right.$ & 3 \\
$\mathrm{n}=\mathrm{N} / 1+\mathrm{N}(\mathrm{e})^{\wedge} 2$ & 66.66667 \\
\hline \multicolumn{2}{c}{ Source: Field Survey $(2020)$}
\end{tabular}

The researcher purposely selected the respondents based on the facts that all of them are eighteen years and above and are either renting or owing a house in Kumalsa community. Purposive sampling technique was then used to select sixty-six (66) respondents in Kulmasa as calculated above.

\section{Sampling Technique}

Ampofo (2020) explains that 'it is imperative for one to determine an aspect of population to be involved in a study, hence purposive sampling technique was used to select 66 respondents who reside in Kulmasa community.

\section{Data Collection Instruments}

Questionnaire and interview guides were used for this study. A questionnaire is a research instrument consisting of series of questions for the purpose of a survey or statistical study (Creswell, 2013). The structured questionnaire type was used. Cohen (2007) and Kusi (2012) explains that a structured questionnaire is a data collection instrument which contains predetermined standard questions or items meant to collect numerical data that can be subject to statistical analyses. The questionnaire was both close ended and open-ended questions with options like (Strongly Agree, Agree, Disagree, Strongly Disagree and Uncertain). It was divided into four sections which are as follows: Section A - Personal data and Section B provides questions on the nature of the existing housing condition in Kumalsa, Section $\mathrm{C}$ on the factors influencing housing development in the community, and Section D on challenges of the existing housing condition in Kumalsa.

\section{Data Analysis Technique}

Analysis of data provided facts and figures that enabled interpretation of the results and reaching conclusions from the findings of the study. All items of the questionnaires were coded. Items in the form of Likert scale were rated between $4-1$, with 4 being the highest and 1 being the lowest. Questionnaires were edited to ensure that clear, legible, relevant, and appropriate responses had been provided. The coded items and their corresponding frequencies were fed into the computer using the SPSS software programme version 20. After entering using SPSS version 20 programme, the computer was used to generate quantitative results including the percentages, and frequencies which was presented in the form of tables and charts.

\section{RESULTS AND DISCUSSION OF RESULTS}

\section{Demographic Data of Respondents}

Section A of the questionnaires gathered data on the sex distribution of respondent's which is presented in the table below. 
Table 2

Sex Distribution of Respondents

\begin{tabular}{lll}
\hline Sex & Frequency & Percentage (\%) \\
\hline Male & 56 & $84.85 \%$ \\
Female & 10 & $15.15 \%$ \\
\hline Total & $\mathbf{6 6}$ & $\mathbf{1 0 0 \%}$ \\
\hline \multicolumn{3}{c}{ Source: Field Survey (2020) }
\end{tabular}

Table 2 presents the gender of participants who responded to the questionnaire items. From the table, 66 respondents were given questionnaire. All the respondents responded to the questionnaire. Majority of the respondents 56 (84.85\%) were males whiles 10 (15.15\%) were females. The implication this is that majority of the people of Kulmasa community who took part in the study and owe house are males.

One aspect of the questionnaire gathered data from respondents on their age and this is what Table 3 presents.

Table 3

\begin{tabular}{lll}
\multicolumn{3}{l}{ Age Distribution of Respondents } \\
\hline Age & Frequency & Percentage (\%) \\
\hline Below 25 & - & - \\
$\mathbf{2 5 - 3 0}$ & 30 & $45.45 \%$ \\
$\mathbf{3 1 - 3 5}$ & 20 & $30.30 \%$ \\
$\mathbf{3 6 - 4 0}$ & 11 & $16.67 \%$ \\
Above 40 & 5 & $7.57 \%$ \\
\hline Total & $\mathbf{6 6}$ & $\mathbf{1 0 0 \%}$ \\
\hline
\end{tabular}

Source: Field Survey (2020)

The age distribution of the sample population is presented in Table 3. The table shows that majority of the respondents were between 25-30 years representing 30(45.45\%) of the respondents. This was followed by those between 31-35 years who also recorded 20(30.30\%), followed by those between 36-40 years representing 11(16.67\%) whiles 5(7.57\%) were above 40 years. The implication of this is that, majority of respondents were older from 25 years which is above the age of maturity as such could give the relevant information needed for this study.

One aspect of the questionnaire also gathered data from respondents on their marital status and this is presented in Figure 1.

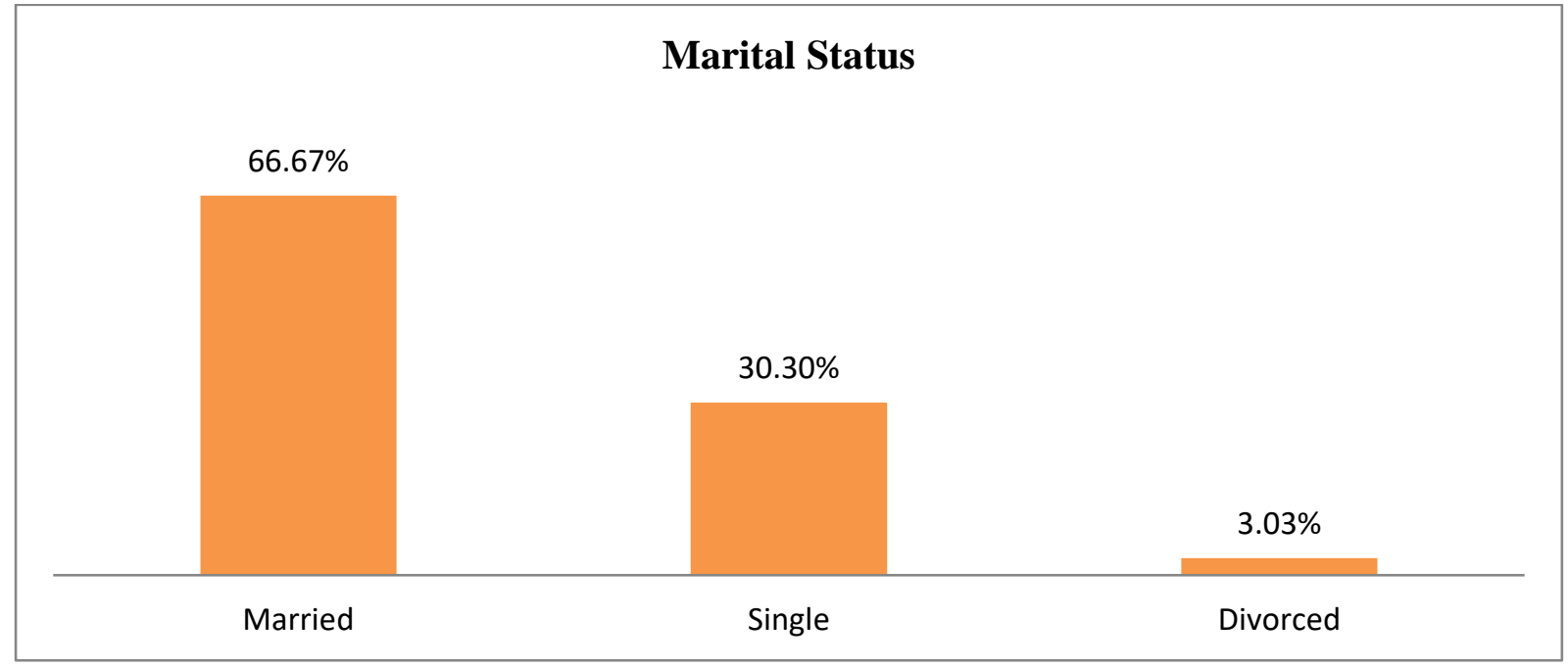

Figure 1; Marital Status of Respondents

Source: Field Survey (2020) 
Results from Figure 1 shows that majority of the respondents 44 out of 66 representing $66.67 \%$ are married, followed by 20 out of 66 representing $30.30 \%$ who indicated that they are single whiles 2 out of the 66 respondents representing 3.03\% indicated that they are divorced. The implication of result in Figure 1 shows that majority of the respondents who took part in this study were married. This was followed by those who were single. One aspect of the questionnaire also gathered data from respondents on their level of education and this is presented in Figure 2.

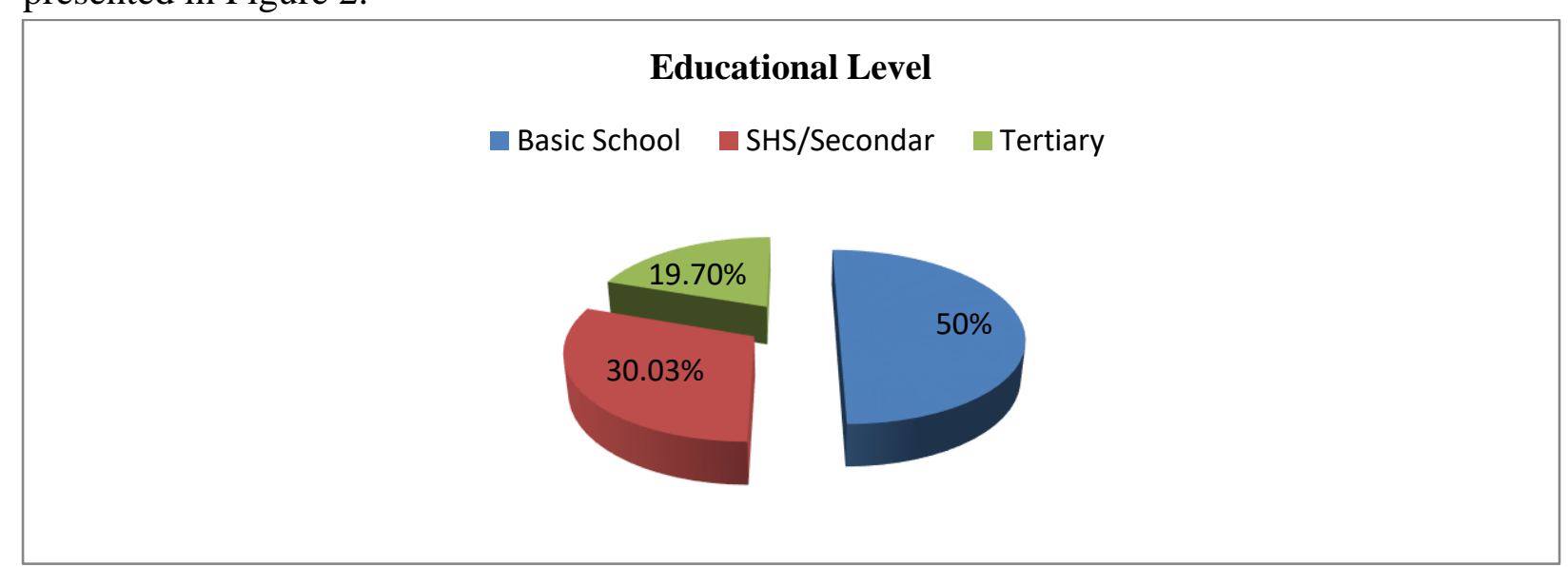

Figure 2: Highest Level of Education of Respondents Source: Field Survey (2020)

Figure 2 shows that majority of the respondents 33 out of 66 representing $50 \%$ have completed basic school, followed by 20 representing $30.03 \%$ who have completed SHS/Secondary whiles 13 (19.07\%) of the respondents have completed. A deduction from the above is that majority of the respondents who took part in this study are basic school graduates. This means that majority of the people in Kulmasa community in the Wa Municipality who took part in the study is educated as such could give the relevant information needed for this study.

Having this in mind, the study sort to investigate in the type of occupation common to the people and this is presented in Figure 3.

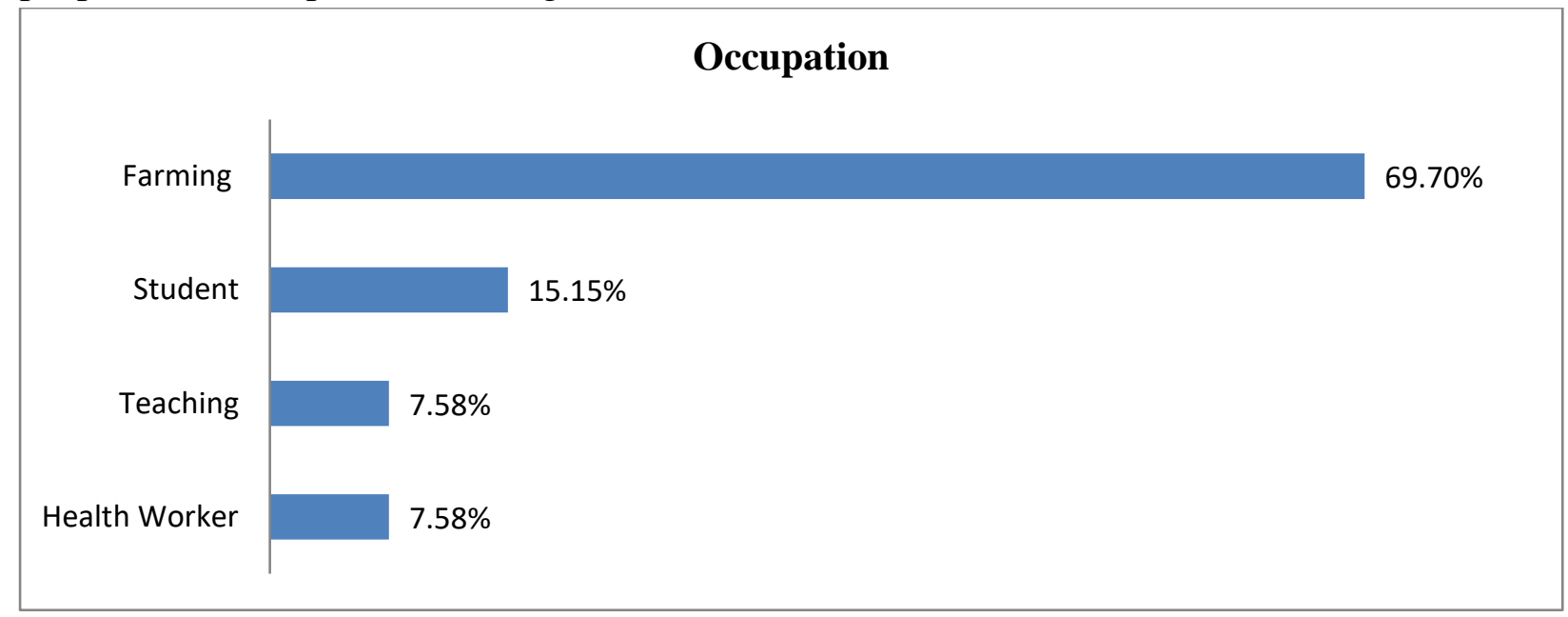

Figure 3: Occupation of Respondents

Source: Field Survey (2020)

From Figure 3, it is quite apparent that majority of the respondents $45(69.70 \%)$ were farmers, followed by $10(15.15 \%)$ who were students, followed by $5(7.58 \%)$ respectively each were 
teachers and health workers. However, since most of them were farmers one would not be too far from right to conclude that most of the people of Kulmalsa community of the Wa Municipality are farmers.

One aspect of the questionnaire also gathered data on the origin of respondents and this is presented in Figure 4.

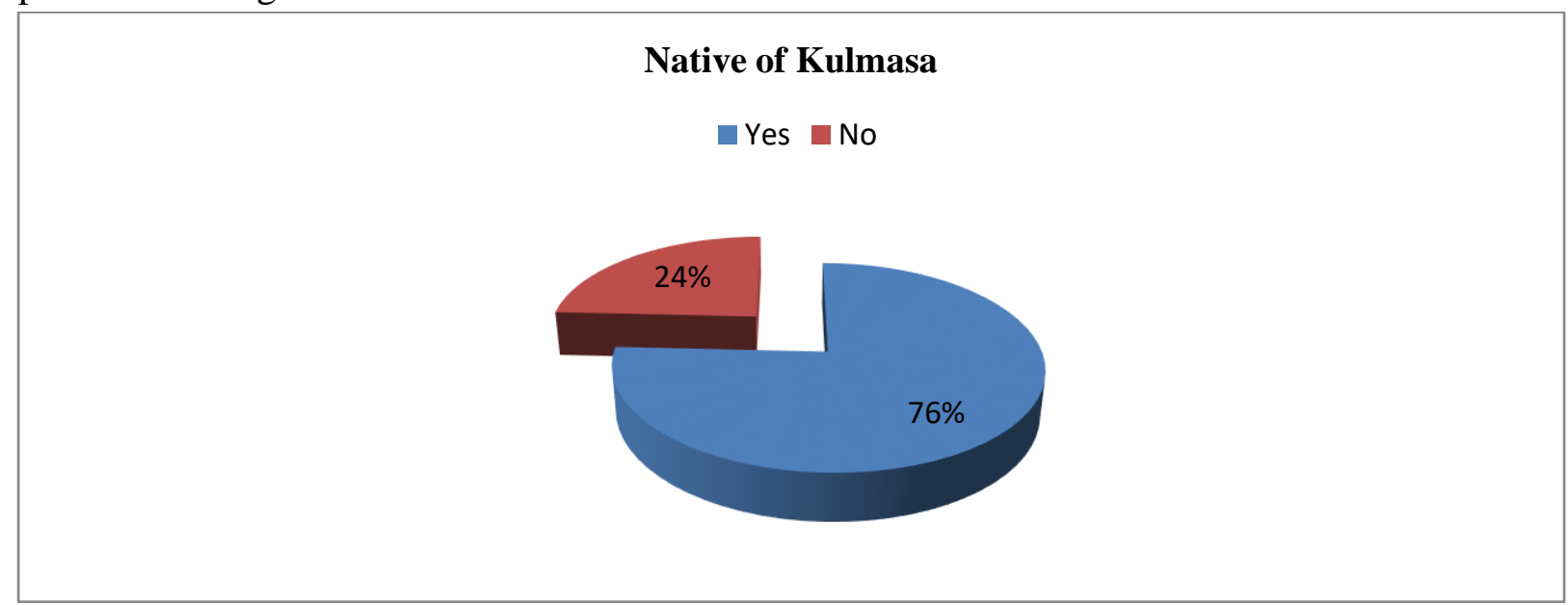

Figure 4: Origin of Respondents as a native of Kulmasa Community

Source: Field Survey (2020)

\section{Analysis of Items}

The analyses of the items are based on the three research questions which are as follows:

1. What is the nature of the existing housing condition in Kulmasa community of the Upper West Region of Ghana?

2. What are the factors influencing housing development in Kulmasa community?

3. What are the challenges of the existing housing conditions in Kulmasa community?

Research Question 1: What is the nature of the existing housing condition in Kulmasa community of the Upper West Region of Ghana?

One aspect of the questionnaire also gathered data from respondents on the house type they lived in Kulmasa of the Upper West Region of Ghana and this is what figure 5 presents.

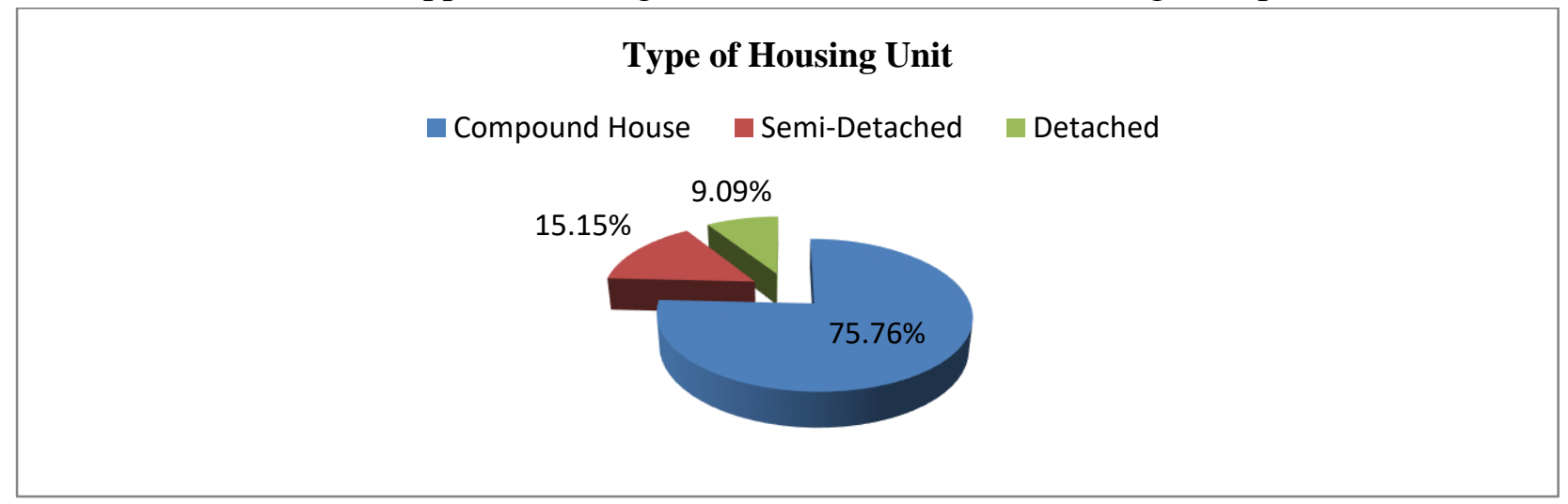

Figure 5: Housing Type in Kulmasa Community

Source: Field Survey (2020)

From Figure 5, majority of the respondents 50 out of 66 representing $75.76 \%$ indicated that their house is a compound house, followed by 10 out of 66 representing $15.15 \%$ who indicated 
that their house is semi-detached whiles 6 out of 66 representing $9.09 \%$ indicated that their house is a detached house.

The three major types of dwelling units are compound houses, semi-detached houses and detached or separated houses. The high proportion of people in compound houses is partly due to the differential cost of the other housing types

One aspect of the questionnaire gathered data from respondents on the ownership of their house and this is presented in Figure 6.

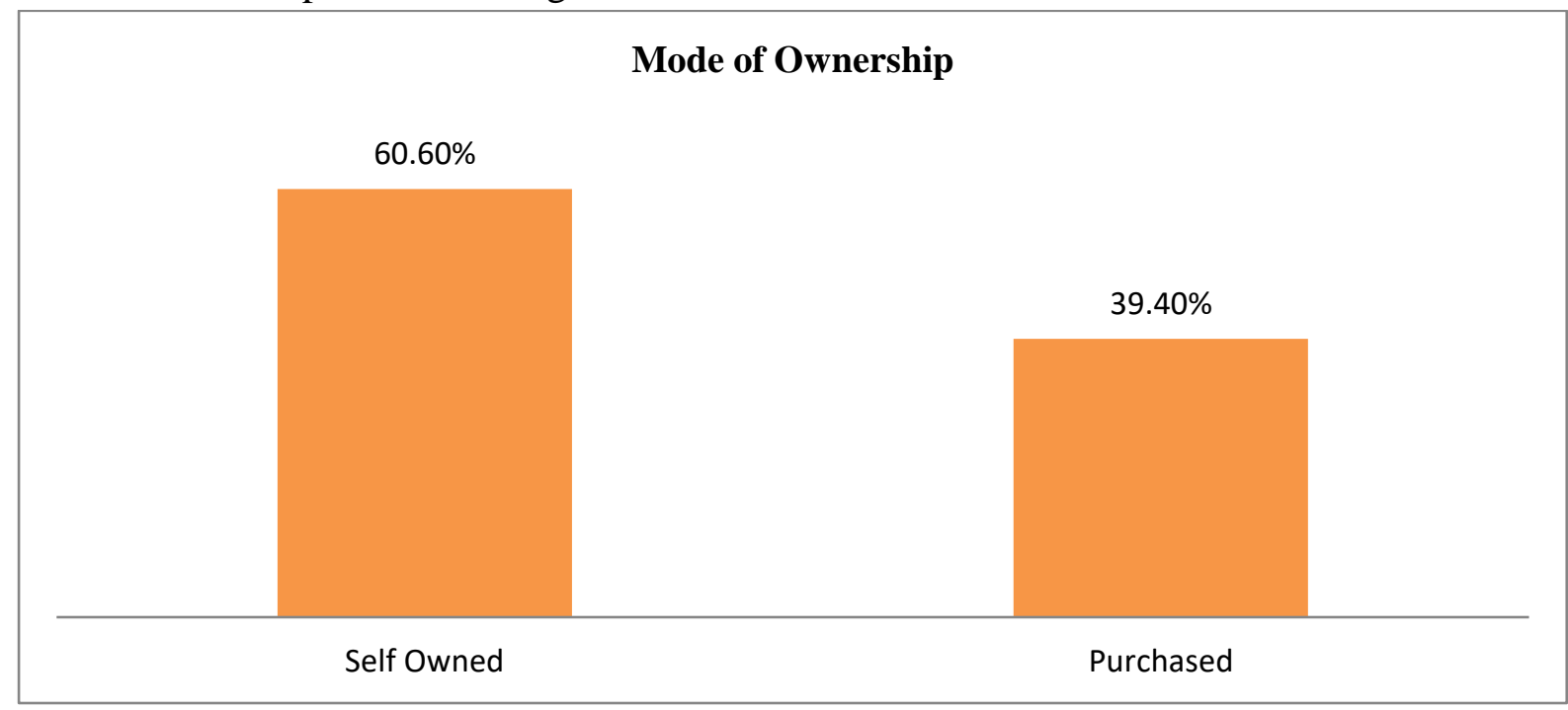

Figure 6: Mode of Ownership of House in Kulmasa Community

Source: Field Survey (2020)

Results from Figure 6 shows that majority of the respondents $40(60.60 \%)$ indicated that they owned the house whiles 26 (39.40\%) indicated that they are renting their house.

One aspect of the questionnaire gathered data from respondents on the level of satisfaction of the existing housing conditions in Kulmasa Community and this is presented in Table 4.

Table 4

Level of satisfaction of existing housing condition in Kulmasa Community of the Upper West Region of Ghana

\begin{tabular}{|c|c|c|c|c|c|c|c|c|}
\hline & $\begin{array}{l}\text { Very } \\
\text { Satisfactory }\end{array}$ & $\begin{array}{l}\text { Moderately } \\
\text { Satisfactory }\end{array}$ & $\begin{array}{l}\text { Slightly } \\
\text { Satisfactory }\end{array}$ & Indifferent & $\begin{array}{l}\text { Not } \\
\text { Satisfactory }\end{array}$ & Mean & $\begin{array}{l}\text { Std. } \\
\text { Dev. }\end{array}$ & Total \\
\hline (F) & 6 & 10 & 30 & 0 & 20 & 2.30 & .266 & 66 \\
\hline$\%$ & $9.09 \%$ & $15.15 \%$ & $45.45 \%$ & $0.00 \%$ & $30.30 \%$ & & & $100.0 \%$ \\
\hline
\end{tabular}

Source: Field Survey (2020)

From Table 4 majority of the respondents 30 (45.45\%) indicated that they are slightly satisfied with the conditions of buildings in Kulmasa, followed by 20 (30.30\%) who indicated that they are not satisfied with the housing conditions in Kulmasa, followed by 10 (15.15\%) who indicated that they are moderately satisfied with the housing conditions in Kulmasa whiles 6 (9.09\%) of the respondents indicated that they are very satisfied with the housing conditions in Kulmasa. The implications of this result is that, the existing housing conditions in Kulmasa community of the Upper West Region is poor.

Research Question 2: What are the factors influencing housing development in Kulmasa community? 
The second objective of the question was to identify the factors influencing housing development in Kulmasa community and this is presented in Table 5.

Table 5

Factors Influencing Housing Development in Kulmasa Community of the Upper West Region of Ghana

\begin{tabular}{|c|c|c|c|c|}
\hline Items & Disagreed & Agreed & (F) & $\%$ \\
\hline Cultural reasons & $\begin{array}{l}26 \\
(39.40 \%))\end{array}$ & $\begin{array}{l}40 \\
(60.60 \%)\end{array}$ & 66 & $100 \%$ \\
\hline Proximity to place of work & $\begin{array}{l}26 \\
(39.40 \%))\end{array}$ & $\begin{array}{l}40 \\
(60.60 \%)\end{array}$ & 66 & $100 \%$ \\
\hline Environmental friendliness of the area & $\begin{array}{l}26 \\
(39.40 \%))\end{array}$ & $\begin{array}{l}40 \\
(60.60 \%)\end{array}$ & 66 & $100 \%$ \\
\hline Accessibility and affordability of the land & $\begin{array}{l}26 \\
(39.40 \%))\end{array}$ & $\begin{array}{l}40 \\
(60.60 \%)\end{array}$ & 66 & $100 \%$ \\
\hline Availability of better infrastructure & $\begin{array}{l}26 \\
(39.40 \%))\end{array}$ & $\begin{array}{l}40 \\
(60.60 \%)\end{array}$ & 66 & $100 \%$ \\
\hline Security reasons & $\begin{array}{l}30 \\
(34.45 \%)\end{array}$ & $\begin{array}{l}36 \\
(55.55 \%)\end{array}$ & 66 & $100 \%$ \\
\hline Proximity to neighbourhood services & $\begin{array}{l}16 \\
(24.24 \%)\end{array}$ & $\begin{array}{l}50 \\
(75.76 \%)\end{array}$ & 66 & $100 \%$ \\
\hline Proximity to recreational activities & $\begin{array}{l}50 \\
(75.76 \%)\end{array}$ & $\begin{array}{l}16 \\
(24.24 \%)\end{array}$ & 66 & $100 \%$ \\
\hline Quietness and serenity of the environment & $\begin{array}{l}50 \\
(75.76 \%)\end{array}$ & $\begin{array}{l}16 \\
(24.24 \%)\end{array}$ & 66 & $100 \%$ \\
\hline Religious reasons & $\begin{array}{l}50 \\
(75.76 \%)\end{array}$ & $\begin{array}{l}16 \\
(24.24 \%)\end{array}$ & 66 & $100 \%$ \\
\hline
\end{tabular}

Source: Field Survey (2020)

Results from Table 5 shows that majority of the respondents $40(60.60 \%)$ respectively each agreed that cultural reasons, proximity to place of work, environmental friendliness of the area, accessibility and affordability of the land and availability of better infrastructure are factors influencing housing development in Kulmasa community of the Upper West Region of Ghana whiles $26(38.40 \%)$ disagreed that cultural reasons, proximity to place of work, environmental friendliness of the area, accessibility and affordability of the land and availability of better infrastructure are factors influencing housing development in Kulmasa Community of the Upper West Region of Ghana. Again, majority of the respondents In addition, majority of the respondents 36 (55.55\%) indicated that, security reasons are factors influencing housing development in Kulmasa community of the Upper West Region of Ghana whiles $30(34.45 \% \%)$ indicated that security reasons again are factors influencing housing development in Kulmasa community of the Upper West Region of Ghana. Again, majority of the respondents $50(75.76 \%)$ agreed that proximity to neighborhood services include factors influencing housing development in Kulmasa Community of the Upper West Region of Ghana while on the other hand, 16 (24.25\%) of the respondents disagreed that proximity to neighborhood services is a factor influencing housing development in Kulmasa community of the Upper West Region of Ghana.

Moreover, majority of the respondents $50(75.76 \%)$ respectively each disagreed that proximity to recreational activities, quietness and serenity of the environment and religious reasons are factor influencing housing development in Kulmasa community of the Upper West Region of Ghana whiles $16(24.24 \%)$ respectively each agreed that that proximity to recreational 
activities, quietness and serenity of the environment and religious reasons are factor influencing housing development in Kulmasa community of the Upper West Region of Ghana. The respondents further expressed that cultural and ethnic reasons were perceived most important factors influencing housing development in the Kulmasa community of the Upper West Region of Ghana. Other factors that also ranked high include proximity to place of work, proximity to friends and families, environmental friendliness of the area, accessibility and affordability of the land and availability of better infrastructure. The result reveals that the respondents place high value on socio cultural values even above neighborhood and infrastructural factors. This finding is in consonance with the study by Danso (2013) who postulated that culture influences housing choices and behaviors.

According to Ghana Statistical Service report in 2005, most rural societies are relatively integrated, in the sense that the various components of life (example; agricultural and nonagricultural, economic, social and political, religious and secular) are closely interrelated. Rural people do not easily recognize the distinctions which planners, extension workers and other government officials make between, for example, the responsibilities of different agencies or economic and social planning, because in their own lives all these things affect each other.

In line with the findings in Danso (2013), cultural values such as kingship and social relations were leading predictors of housing development in most developing countries followed closely by religious consideration. Thus, an integrated approach to planning that will meet the yearnings of rural dwellers must not only be limited to the planning point of view (e.g. the agricultural or the economic) but take account of other related aspects of kingship, social relations and religion. The implication of this is that whatever form housing development initiatives may take, adequate cognizance must be taken to ensure that the people get satisfaction on matters that border on their culture and ethnicity. Some neighborhood factors, infrastructural and security factors are also deemed to be of priority. Factors deemed less important include proximity to recreational activities, quietness and serenity of the environment and religious reasons.

Research Question 3: What are the challenges of the existing housing conditions in Kulmasa community?

The third research question seeks to assess the challenges of the existing housing conditions in Kulmasa community and this is presented in Table 6.

Table 6

Challenges of the existing housing conditions in Kulmasa community of the Upper West Region of Ghana

\begin{tabular}{lllll}
\hline Items & Disagreed & Agreed & $(\mathbf{F})$ & \% \\
\hline Inadequate infrastructure & 0 & 66 & 66 & $100 \%$ \\
& $(0.00 \%)$ & $(100.0 \%)$ & & \\
Inadequate capital to build & 0 & 66 & 66 & $100 \%$ \\
& $(0.00 \%)$ & $(100.0 \%)$ & & \\
High building cost & 0 & 66 & 66 & $100 \%$ \\
& $(0.00 \%)$ & $(100.0 \%)$ & & \\
Unavailability of building materials in the locality & 66 & 0 & 66 & $100 \%$
\end{tabular}




\begin{tabular}{|c|c|c|c|c|}
\hline & $(100.0 \%)$ & $(0.00 \%)$ & & \\
\hline Difficulty in accessing land for building & $\begin{array}{l}0 \\
(0.00 \%)\end{array}$ & $\begin{array}{l}66 \\
(100.0 \%)\end{array}$ & 66 & $100 \%$ \\
\hline Inadequate expertise to handle desired building style & $\begin{array}{l}56 \\
(84.85 \%)\end{array}$ & $\begin{array}{l}10 \\
(15.15 \%)\end{array}$ & 66 & $100 \%$ \\
\hline Unaffordable housing structure & $\begin{array}{l}0 \\
(0.00 \%)\end{array}$ & $\begin{array}{l}66 \\
(100.0 \%)\end{array}$ & 66 & $100 \%$ \\
\hline Inaccessible public housing structure & $\begin{array}{l}0 \\
(0.00 \%)\end{array}$ & $\begin{array}{l}66 \\
(100.0 \%)\end{array}$ & 66 & $100 \%$ \\
\hline High price of land & $\begin{array}{l}0 \\
(0.00 \%)\end{array}$ & $\begin{array}{l}66 \\
(100.0 \%)\end{array}$ & 66 & $100 \%$ \\
\hline Low income level of people & $\begin{array}{l}0 \\
(0.00 \%)\end{array}$ & $\begin{array}{l}66 \\
(100.0 \%)\end{array}$ & 66 & $100 \%$ \\
\hline
\end{tabular}

Results from Table 6 shows that all the respondents 66 (100\%) respectively each agreed that inadequate infrastructure, inadequate capital to build, high building cost, difficulty in accessing land for building, inaccessible public housing structure, high price of land, low income level of people and unaffordable housing structure are challenges of the existing housing conditions in Kulmasa community of the Upper West Region of Ghana.

In addition, majority of the respondents $66(100 \%)$ disagreed that unavailability of building materials in the locality is a challenge of the existing housing conditions in Kulmasa community of the Upper West Region of Ghana. Again, majority of the respondents 56 $(84.85 \%)$ disagreed that inadequate expertise to handle desired building style is a challenges of the existing housing conditions in Kulmasa community of the Upper West Region of Ghana whiles $10(15.15 \%)$ of the respondents agreed that inadequate expertise to handle desired building style is a challenges of the existing housing conditions in Kulmasa community of the Upper West Region of Ghana.

All the respondents further expressed that lack of access to secure land, limited access to finance, high cost of land registration, slow bureaucratic procedures, lack of infrastructure in rural areas, development controls, uncoordinated policies and implementations, high cost of construction and high price of land are some of the challenges of the existing housing conditions in Kulmasa community of the Upper West Region of Ghana. It is regrettable that in spite of the policies, institutions and regulations which various Ghanaian Governments have put in place since independence, the task of instituting efficient, effective, affordable and sustainable housing delivery processes continues to challenge policy makers even as the problems of the housing sector worsens.

This has been attributed to multiplicity of factors which includes lack of secure access to land, high cost of construction, limited access to finance, bureaucratic procedures, high cost of land registration and titling, uncoordinated policies and ownership rights under the Land Registration Act, lack of critical infrastructure like roads, affordability gap, inefficient development control, youths harassment of developers, inelegant revocation and compensation process among others.

This result is in tandem with Bank of Ghana report in 2007, which shows that inadequate and unreliable infrastructure services are common in the majority of rural communities in Africa. According to Aboagye (2011) sustainable housing should therefore focus on issues relating to affordability and improvement in housing quality through better infrastructure. These housing 
challenges recorded are peculiar to rural areas (Ampofo, 2020) and are traceable to weak rural development structure and less concentration of development effort on rural areas relative to urban areas.

Land accessibility, according to Alan (2008) entails land tenure security, land affordability, land availability and the ease with which land is acquired. Kumar (2001) opines that extensive and intensive literature searches reveal consensus among analysts that accessibility to land poses the greatest difficulty to urban housing production in many developing countries. Evidence abounds in urbanization studies in developing countries to buttress the fact that where land has been made available, even the poor have been able to provide themselves with some form of housing (Yeboah, 2005). Thus, of all the ingredients of housing, land is of paramount importance. There is need to particularly focus on the development of housing in the rural areas because a considerable proportion of Ghanaians live in the rural areas (Yebaoh, 2005).

According to Alan (2008) the relationship between the urban and rural areas are symbiotic and if any development strategy must be successful, it must recognize that the phenomenon of rural - urban dichotomy in the national landscape is unacceptable and connotes underdevelopment. According to Kwofie (2011) many areas in Ghana suffer from severe pressures on available resources, such as housing, thereby worsening already bad situations in urban employment, management, service delivery and livability.

Despite having a considerable proportion of the national population, the rural areas are characterized by pervasive and endemic poverty, manifested by widespread hunger, malnutrition, poor health, inadequate access to formal education, deplorable housing state and various forms of social and political menace. Most of these challenges are not as severe in urban areas when compared to the rural areas.

\section{SUMMARY OF MAJOR FINDINGS}

The study sought to assess the housing challenges in Kulmasa of the Upper West Region of Ghana. With regard to the specific objectives of the study, the findings are discussed in subsections below.

The first objective of this study seeks to determine the nature of the existing housing conditions in Kulmasa community of the Upper West Region of Ghana. The study found out that the existing housing conditions in Kulmasa community in the Wa Municipal is substandard. The study has evaluated factors responsible for rural housing development in Kulmasa in the Wa Municipal and has established a huge gap in meeting the housing needs of the rural populace. In spite of the importance of rural areas in enhancing national development, the study found gross dissatisfaction of rural dwellers with the available housing condition in Kulmasa. This hangs largely on the inadequacy of infrastructure and high cost of housing development.

The second objective of the study seeks to identify the factors influencing housing development in Kulmasa community. The study found out that cultural reasons, proximity to place of work, environmental friendliness of the area, accessibility and affordability of the land and availability of better infrastructure are factors influencing housing development in Kulmasa Community of the Upper West Region of Ghana. The study also found out that housing development is driven at rural areas by the need to preserve their cultural beliefs and value which requires indigenes to have a family house built in their place of origin in line with 
the design and features that are in vogue and in compliance with the acceptable norms of the people of the areas.

The third research objective seeks to assess the challenges of the existing housing conditions in Kulmasa. The study found out that lack of access to secure land, limited access to finance, high cost of land registration, slow bureaucratic procedures, lack of infrastructure in rural areas, development controls, uncoordinated policies and implementations, high cost of construction and high price of land are some of the challenges of the existing housing conditions in Kulmasa community of the Upper West Region of Ghana.

\section{CONCLUSIONS}

Conclusions were drawn based on the research findings:

The study concluded that the existing housing conditions in Kulmasa community in the Wa Municipal are substandard. The study also concluded that in spite of the importance of rural areas in enhancing national development, the study found gross dissatisfaction of rural dwellers with the available housing condition in Kulmasa community in the Wa Municipality of the Upper West Region of Ghana.

The study further concludes that cultural reasons, proximity to place of work, environmental friendliness of the area, accessibility and affordability of the land and availability of better infrastructure are factors influencing housing development in Kulmasa Community of the Upper West Region of Ghana.

Lastly the study concluded that, lack of access to secure land, limited access to finance, high cost of land registration, slow bureaucratic procedures, lack of infrastructure in rural areas, development controls, uncoordinated policies and implementations, high cost of construction and high price of land are some of the challenges of the existing housing conditions in Kulmasa community of the Upper West Region of Ghana.

\section{Recommendations}

The researcher recommends to the government of Ghana to provide enabling environment for private sector to provide safe, adequate and affordable housing for people in rural communities in Ghana. Furthermore, the study recommends that the Ministry of Works and Housing and Ministry of Sanitation and Environment should liaise with professionals in the construction industry to organize a housing summit in the Kulmasa community in the Wa Municipality of the Upper West Region of Ghana on an effective and efficient housing.

Moreover, the study recommends that formal and informal land delivery systems should be encouraged to ensure secure and easy access to land, titling, transfer and foreclosure in the Kulmasa community of the Upper West Region of Ghana. Again, the study recommends that the government of Ghana should liaise with banks and set up social housing mortgage scheme. This entails interested banks pooling reasonable sum of money together for lending to the people of Kulmasa at a negotiated but reduced interest rate of say $5 \%$ or less.

Furthermore, the study recommends that the government of Ghana through the Wa Municipal Assembly should establish more serviced residential layouts and provide infrastructures in old residential layouts to serve as catalyst for housing development and delivery in Kulmasa community. Lastly to reduce the high cost of construction in the Kulmasa community, the blending of imported building materials and local materials should be encouraged; effective 
and functional architectural designs adopted and skill acquisition centres established in Wa Municipal.

\section{Acknowledgements}

The researcher wants to thank the editorial board of Fair East Publishers.

\section{Conflict of Interest Statement}

No conflict of interest has been declared by the author.

\section{Funding}

The researcher has not received any support for the publication of this paper.

\section{References}

Aboagye, A., \& Sarpong-Kumankoma, E. (2011). Housing and Construction Finance, Deposit Mobilisation and Bank Performance in Ghana. Journal of Property Research, 28(2), $51-65$

Alan, G. (2008). A policy guide to rental housing in developing countries. UNON, Publishing Services Section, Nairobi, ISO 14001:2004-certified.

Ampofo, A. J. (2020). Constraints factors to maintenance of government senior high school buildings in Wa Municipal. International Journal of Management \& Entrepreneurship Research, 2(3), 139-160.

Ampofo, A. J., Amoah, S. T., \& Peprah, K. (2020). Examination of the current state of government buildings of senior high schools in Wa Municipal. International Journal of Management \& Entrepreneurship Research, 2(3), 161-193.

Ampofo, A. J., Nassè, T. B., Amoah, S. T., \& Peprah, K. (2020). Stakeholders responsibilities in public SHS buildings maintenance practices in the Wa Municipality. International Journal of Management \& Entrepreneurship Research, 2(3), 109-139.

Ampofo, A. J. (2019). Performance management and appraisal in improving teacher's quality: Lambert Academic Publishing.

Ampofo, A. J. (2017). Community and parental influence on Senor High School (SHS) student's career choice: Lambert Academic Publishing.

Bank of Ghana (2007). The Housing Market in Ghana: Prospects and Challenges. [Online] Available at http://www.bog.gov.gh/privatecontent/Research/PolicyBrief/pbriefhousing-new.pdf (April, 2018)

Creswell, J.W. (2013). Qualitative inquiry and research design: Choosing among five approaches ( $3^{\text {rd }}$ edn.). Thousand Oaks: Sage.

Cohen, L., Manion, L., \& Morrison, K. (2007). Research Methods in Education (6 $6^{\text {th }}$ edn.). London: Routledge.

Danso, H., \& Manu, D. (2013). High Cost of Materials and Land Acquisition Problems in the Construction Industry in Ghana. International Journal of Research in Engineering \& Applied Sciences. Available at: http://www.euroasiapub.org/IJREAS/mar2013/3.pdf (April, 2018)

Ghana Statistical Service. (2005), 2000 Population and Housing Census. 
Hite, S. (2010). Reviewing quantitative research to inform educational policy processes. United Nations Educational, Scientific and Cultural Organization, Paris. France.

Kumar, S. (2001). Social relations, rental housing markets and the poor in urban India. Final Report to DFID.

Kwofie, T. E., Botchway, E. \& Adinyira, E. (2011). Historical overview of housing provision in pre and post- independence Ghana.

Kusi, H. (2012). Doing Qualitative Research: A guide for researchers. Accra New Town: Emmpong Press.

Lee, R. (2000). Unobtrusive Methods In Social Research. Open University Press. Buckingham. U.K.

UN-Habitat (2010). Housing as a Strategy for Poverty Reduction in Ghana. United Nations Human Settlements Programme (UN-HABITAT). Available at: www.unhabitat.org [April, 2018]

UN-Habitat (2011;2012). Ghana Housing Profile. Available at: www.unhabitat.org (April, 2018]

Yeboah, E.A. I. (2005). Housing the urban Poor in Twenty-First Century Sub Sahara Africa: Policy Mismatch and a Way Forward for Ghana. Geo journal 62(2), 147-16. York: Harper and Row. 